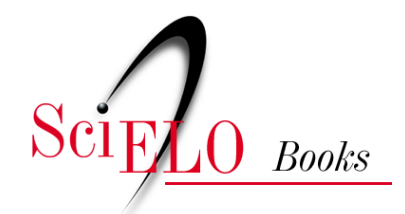

EDUFU

\title{
O ensino do teatro de animação
}

\author{
Valmor Níni Beltrame
}

SciELO Books / SciELO Livros / SciELO Libros

BELTRAME, V.N. O ensino do teatro de animação. In: FLORENTINO, A., and TELLES, N., eds. Cartografias do ensino do teatro [online]. Uberlândia: EDUFU, 2008, pp. 283-297. ISBN 978-857078-518-3. https://doi.org/10.7476/9788570785183.0028.

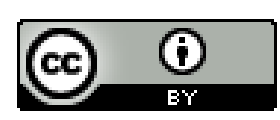

All the contents of this work, except where otherwise noted, is licensed under a Creative Commons Attribution 4.0 International license.

Todo o conteúdo deste trabalho, exceto quando houver ressalva, é publicado sob a licença Creative Commons Atribição $\underline{4.0}$.

Todo el contenido de esta obra, excepto donde se indique lo contrario, está bajo licencia de la licencia $\underline{\text { Creative Commons }}$ Reconocimento 4.0. 


\section{O ENSINO DO TEATRO DE ANIMAÇÃO}

Valmor Nini Beltrame

O teatro de animação constitui um campo artístico que compreende as linguagens do teatro de máscaras, sombras e bonecos/objetos. Cada uma destas linguagens possui técnicas e especificidades que obedecem a regras e a um vocabulário próprio. $\mathrm{O}$ ensino dessa arte deve contemplar alguns eixos fundamentais: o estudo de sua história; o conhecimento do Mamulengo, teatro de bonecos popular brasileiro; a confecção de bonecos e a montagem de cenas, nas quais os princípios técnicos dessa linguagem sejam utilizados.

A inclusão do ensino de teatro de animação em universidades brasileiras é bastante recente. Iniciou-se por volta de 1980 e deve ser creditada principalmente a duas instituições: a Escola de Belas Artes da Universidade Federal de Minas Gerais e a Escola de Comunicações e Artes da Universidade de São Paulo. Hoje, a atividade se expandiu para outras universidades brasileiras, principalmente junto aos cursos de Licenciatura em Artes Cênicas.

O estudo que segue pretende discutir alguns dos eixos a serem contemplados no ensino do teatro de animação no âmbito acadêmico, com ênfase na linguagem do teatro de objetos/bonecos. A idéia é formular uma proposta que possa contribuir na formação acadêmica do artista professor interessado em trabalhar com essa linguagem.

\section{As vanguardas históricas e o teatro de animação}

Os últimos anos do século XIX e os primeiros do século XX são marcados pelo crescente interesse de dramaturgos e encenadores pela marionete. A marionetização do ator, a substituição do ator por bonecos, por formas, e a humanização de objetos são discussões que animam a produção teatral. Em torno dessa discussão, estão artistas que negam a estética do romantismo, do melodrama e do realismo enquanto correntes artísticas, e se abrigam sob o movimento simbolista. Tal interesse aparece de forma visível em duas direções: a marionete como referência para o comportamento do ator em cena e o teatro de marionetes como gênero artístico. Destaca-se, desse modo, o fascínio pela marionetização do trabalho do ator e experimentações em torno da humanização de objetos. 
Encenadores e dramaturgos, decepcionados com a atuação dos atores, seu histrionismo, excessos, caretas e condicionamentos psicofísicos, expressam a necessidade de o ator assumir outro comportamento em cena e apontam a marionete como referência para seu trabalho. Na raiz dessa discussão está a defesa do controle sobre o trabalho do ator, a ser efetuado pelo diretor; a negação do espontaneísmo e do vedetismo (predominantes no comportamento dos atores naquela época); a teatralização do teatro; a necessidade de consolidar a função do diretor como o maior responsável e criador do espetáculo teatral.

Hoje, o ator marionetizado pode ser visto como o "ator perfeito", o ator que com seus gestos e movimentos precisos, refinados, atingiu o ideal de beleza. Trata-se do ator que abandona a condição de vedete e uma atuação pautada na gestualidade cotidiana. Ele deixa de lado as características de seu comportamento diário, os traços marcantes da sua personalidade para realizar uma outra experiência, distanciada das propostas de interpretação realista e naturalista. É o ator que atingiu a capacidade de representar a personagem sem mesclar suas emoções e personalidade. Esse aparente "desumanizar-se" revela a essência humana. No seu trabalho, utiliza recursos técnicos comuns ao trabalho do ator-animador: a economia de meios, a precisão de gestos e movimentos, o olhar como indicador da ação, o foco, a triangulação, a partitura de ações, o subtexto; a idéia de que o movimento é frase, além de outros aspectos técnicos utilizados na animação de bonecos e objetos ${ }^{1}$.

A proposta de interpretação tendo a marionete como referência foi construída com a colaboração de diversos pensadores, dentre os quais se destacam Heinrich Von Kleist, Maurice Maeterlinck, Alfred Jarry, Edward Gordon Craig e Vsévolod Meyerhold. Ao estudar o pensamento desses dramaturgos e encenadores, é importante evidenciar pontos comuns e divergências em relação à idéia de marionetização do ator e, ao mesmo tempo, destacar que essas idéias vão influenciar o trabalho de marionetistas na produção de espetáculos cada vez mais heterogêneos.

O ator perfeito de Kleist - Heinrich Von Kleist (1777-1811) foi um dos pioneiros nessa discussão ao publicar o ensaio Sobre o Teatro de Marionetes, em 1810, cujas idéias passaram a animar polêmicas entre encenadores.

No diálogo estabelecido entre a personagem Senhor C e o primeiro bailarino da Ópera da cidade, Kleist diz que a marionete é o verdadeiro artista, porque dispõe de qualidades como euritmia, mobilidade e leveza. Ela pode realizar movimentos com graça, impossíveis de serem conseguidos pelo ser humano, porque o homem não tem controle sobre o centro de gravidade do movimento. E outra vantagem decisiva é que a marionete não é "afetada", como ocorre com a maioria dos atores e bailarinos.

Depois de discorrer sobre o movimento, sobre os deslocamentos e sua relação com o centro de gravidade, e de afirmar que estes devem ser conseguidos pelo controle externo, Kleist evoca um ator meio máquina, meio deus, capaz de realizar os desejos da alma e encarnar o homem como criador do mundo.

\footnotetext{
${ }^{1}$ Diversos espetáculos teatrais brasileiros utilizam esse procedimento: $U B U$, do Grupo Sobrevento; Buster, do Grupo XPTO; espetáculos dirigidos por Gerald Thomas, como Electra com Creta, Trilogia Kafka, M.O.R.T.E. No teatro europeu e norte-americano, destacam-se espetáculos dirigidos por Mnouchkine, Bob Wilson, Leszek Madzik. No cinema recente, são notáveis as atuações das atrizes Kati Outinem, em O Homem sem Passado, de Aki Kaurismaki; e Scarllet Johansson, em A Moça com Brinco de Pérola, de Peter Weber.
} 
O ator desencarnado de Maeterlinck - Maurice Maeterlinck (1862-1949), dramaturgo simbolista, apelava para a palavra pura, em que a verbalização o ator seria quase uma estátua falante, adquirindo uma sobriedade gestual com movimentos que obedeceriam a princípios de economia, contenção e elegância, imobilidade e face congelada, explorando silêncios. Insistia em que o espectador, ao ver homens materialmente representados e personagens se expressando em linguagem comum, percebia na cena um caso e um indivíduo e não o ser humano universal. E afirmava:

Talvez fosse necessário suprimir totalmente o ser humano da cena... Ou - quem sabe - o ser humano poderá ser substituído por uma sombra, um reflexo, projeções numa tela de formas simbólicas ou por um ser com toda a aparência da vida, sem ter vida. Eu não sei, mas a ausência do homem me parece indispensável².

Fica evidente que o que contrariava o autor era a presença física do ator - se mexendo, falando -, porque acreditava que isso destruía a ficção e impunha a realidade concreta, e limitada, de homens em seu cotidiano. Como se a realidade não conseguisse dar conta da verdade da existência. E tudo o que o ator fazia parecia ridículo, inadmissível, intolerável.

As indicações para a nova forma de interpretar são genéricas, mas fica claro que o ator precisa encontrar novos meios de expressão, cujas referências estariam, talvez, nas marionetes, nas figuras de cera, nos autômatos, nos andróides, nos reflexos, objetos, máscaras.

O ator boneco de Jarry - Alfred Jarry (1873 -1907) foi um dos precursores do retorno ao uso da máscara e pela busca de uma interpretação "despersonalizada", tendo como referência a marionete. Ele propôs um teatro no qual as máscaras substituem o retrato sociológico de uma pessoa pela "efígie da personagem". Na estréia da peça $U b u R e i$, em discurso para a platéia afirmava:

Nestas noites, os atores quiseram tornar-se impessoais e representar cobertos por máscaras demonstrando mais precisamente o homem interior e a alma das marionetes que vocês vão ver [...]. Estarão cobertos por uma máscara com o caráter da personagem: o avarento, fraco, sovina, criminoso ${ }^{3}$.

Jarry fazia a defesa da personagem tipificada, a negação da personagem psicologizada. Referindo-se ao boneco e ao ator que usa máscara, salientava que ambos devem se mover pouco e lentamente, com o fim de oferecer ao espectador uma imagem ambígua, afastada do contexto do qual surgiram.

As referências do teatro de marionetes presentes nas personagens da peça Ubu Rei são evidentes pelas mudanças bruscas das suas reações; pela rapidez com que mudam de atitudes e opiniões; pela coexistência de atitudes próximas da vulgaridade; pela proximidade entre o bom senso e a idiotice, entre a nobreza e a infâmia.

${ }^{2}$ MAETERLINCK, Maurice. Menus propus, le théâtre. In: PLASSARD, Didier. Les mains de lumière. Charleville-Mézières: Institut International de la Marionnette, 1996. p. 20.

${ }^{3}$ JARRY, Alfred. Todo ubú. Barcelona: Bruguera, 1980. p. 24. 
O ator máscara de Craig - Edward Gordon Craig (1872-1966) criticava a estética realista dando a impressão da impossibilidade de o ator estar em cena. Dentre as polêmicas afirmações do autor, destaca-se esta afirmativa: "A representação do ator não constitui uma arte; e é forçadamente que se dá ao ator o nome de artista. Porque tudo o que é acidental é contrário à arte" ${ }^{4}$.

A publicação do seu ensaio O Ator e a Supermarionete, em 1908, expressava sua rejeição ao teatro produzido na época. Negava a arte realista como imitação fotográfica da natureza, o teatro em que predomina a submissão ao texto, o teatro escrito, a interpretação submetida aos caprichos e emoções humanos. Dizia que os gestos do ator, a expressão de seu rosto, da sua voz, não obedecem a controles e se traem constantemente. E desafiava:

Suprima-se a árvore autêntica que se colocou em cena, suprima-se o tom natural, o gesto natural e chegar-se-á igualmente a suprimir o ator. [...]

O ator desaparecerá e em seu lugar veremos uma personagem inanimada que usará, se quereis, o nome de Sur-marionnette - até que tenha conquistado um nome mais glorioso 5 .

O pesquisador francês Plassard, ao manusear escritos de Craig dos anos 1905 e 1906, período em que este último formulou a idéia da Supermarionete, conclui:

Meus estudos constatam já nas primeiras páginas do Caderno A que a idéia de supermarionete não está separada do ator usando máscara, em parte inspirado no ator do teatro antigo grego. Notas e croquis demonstram o ator inteiramente coberto, despersonalizado, com máscara, tornando impossível ao intérprete mesclar suas emoções e personalidade na representação da personagem ${ }^{6}$.

Craig lançou as bases de uma tendência que se consolidaria mais tarde: a teatralização do teatro, instaurando o monopólio da figura do diretor na cena. Para ele, o ator é a Supermarionete, uma máscara cobrindo além do rosto, todo o corpo do ator.

A polifonia meyrholdiana - Para o diretor Vsévolod Meyerhold (1874 1940), o teatro de bonecos popular russo, o Petrushka, é referência importante na preparação do seu elenco. Ele via na síntese dos movimentos conquistas que seu elenco deveria fazer. $\mathrm{O}$ ator Igor Iliinski relata exercícios propostos pelo diretor:

Meyerhold apreciava altamente a expressividade do corpo. Fazia a demonstração com um boneco de guinhol: introduzindo os dedos, obtinha os efeitos mais diversos. Apesar da sua máscara parada, o boneco exprimia quer a alegria - os braços abertos, como a tristeza - a cabeça caída, ou ainda o orgulho - a cabeça inclinada para trás ${ }^{7}$.

\footnotetext{
${ }^{4}$ CRAIG, Edward Gordon. Da arte do teatro. Lisboa: Arcádia, 1973. p. 87.

${ }^{5}$ CRAIG, 1973, p. 108-109.

${ }^{6}$ PLASSARD, Didier. L'acteur en Effigie. Paris: L'Age D'Homme, 1992. p. 47-53.

7 ILIINSKI apud MEYERHOLD, Vsévolod. O teatro teatral. Lisboa: Arcádia, 1980. p. 189.
} 
O boneco é referência importante na superação da interpretação psicológica, colaborando para a expressividade do gesto, precisão e síntese do movimento.

Em seu estudo O Teatro de Feira (1912) recorre à marionete para marcar a diferença entre o "ator da interioridade" e o ator de uma linguagem cênica original. Para ele, o primeiro "só busca revelar seu estado de alma pessoal. Recusa-se a obrigar sua vontade a dominar os procedimentos técnicos". Ao segundo, perguntava: "ele deve substituir a marionete e perseguir esse papel auxiliar, que lhe recusa toda liberdade de criação pessoal, ou deve fundar um teatro análogo ao que a marionete soube conquistar, negando-se a se submeter à vontade do diretor de modificar a sua natureza?"8. Ele mesmo respondia dizendo:

A marionete não quer se identificar completamente ao homem, porque o mundo que ela representa é o maravilhoso mundo da ficção, porque o homem que ela representa é um homem inventado, porque o tablado onde ela evolui é o espaço de harmonia onde se encontram os fios de sua arte. Sobre seus tablados, é assim e não de outra maneira, não de acordo com as leis da natureza, mas porque essa é a sua vontade, e porque o que ela quer não é copiar, mas criar?

A idéia de marionetização em Meyerhold apresenta-se de maneira diferenciada, eventualmente o boneco é referência para que o ator elabore o que ele considera essencial: a construção de uma técnica particular fundada na expressividade do gesto e do corpo. $\mathrm{O}$ ator, criador dessa nova forma de interpretar, distancia-se da cópia pura e simples da natureza para chegar à harmonia plástica, à criação artística. Usa o boneco na cena com freqüência; porém, como alegoria, figuração, metáfora da personagem que representa. Conforme Krisinski1 ${ }^{10}$, "Meyerhold propõe um teatro sincrético e polifônico que integre o boneco, sem outorgar-lhe a função primordial de símbolo absoluto”.

Com Maeterlinck, Jarry, Craig e Meyerhold é possível perceber a existência de eixos, para analisar o trabalho do ator marionete. São tendências que por vezes se apresentam profundamente imbricadas e noutros momentos parecem tomar rumos distintos.

De acordo com Jarry, o ator é boneco com comportamento cênico e inclui uma gestualidade desconcertante. O boneco é referência tanto para a construção da personagem em seus textos dramáticos como para a interpretação.

Craig explora, através da marionete e suas múltiplas formas, as condições de reorganização do jogo teatral em linguagem única, numa homogeneidade plástica, em que o ator é tão somente parte integrante de uma totalidade mais ampla: o espetáculo. $\mathrm{O}$ ator inteiramente mascarado é quem pode concretizar essa forma de interpretar no novo teatro.

Já Maeterlinck desenha o perfil de um ator mediado pelo visível e o invisível. O ator é o ser desencarnado, símbolo do homem submetido ao servilismo absoluto de normas sociais estabelecidas.

\footnotetext{
${ }^{8}$ MEYERHOLD, Vsévolod. Le théâtre de foire. In: PLASSARD, Didier. Les mains de lumière. Charleville-Mézières: Institut International de la Marionnette, 1996. p. 232.

9 MEYERHOLD, 1996.

${ }^{10}$ KRISINSKI, Wladimir. Un desorden sofisticado. In: PUCK: el títere y las otras artes: cuerpos en el espacio. Bilbao: Institut International de la Marionnette: Centro de Documentación de Títeres de Bilbao, 1992. n. 4, p. 19.
} 
Para Meyerhold, o Petrushka eventualmente é referência tanto para a encenação quanto para a formação do elenco. $\mathrm{O}$ diretor buscava a teatralidade e assim torna relativa a função do boneco, integrando-o à simultaneidade de outros recursos, fazendo- o colaborar com a polifonia cênica em que se constituíam seus espetáculos.

Mas é possível perceber um eixo comum nos autores estudados: a marionete sempre aparece como síntese dessa nova forma de teatro, em que o espetáculo se aproxima do cálculo matemático, obedecendo a regras e normas de visibilidade cênica, compreendendo movimento, cores, gestos, sons, ritmo. Aí está a espetacularidade no teatro apoiada na marionete, num momento da história em que o teatro se rebela contra a encenação realista e a interpretação psicológica. Para esses dramaturgos e diretores, vale insistir, a marionete é referência, por vezes síntese da perfeição, rumo a essa nova forma de interpretar e conceber a arte do teatro.

No ensino do teatro de animação é relevante estudar as trajetórias desses dramaturgos e diretores, porque demonstram a importância do teatro de marionetes como caminho na formulação de propostas para um novo teatro, no qual as fronteiras entre diferentes linguagens artísticas já eram tênues; evidencia um período da história do teatro marcado pela inquietude, pela irreverência e pela rebeldia contra as distintas formas de um teatro comercial.

Mamulengo - Em alguns estados do Nordeste brasileiro e mais especialmente no estado de Pernambuco, existe uma forma de teatro de bonecos conhecida como mamulengo ${ }^{11}$. É uma arte praticada por artistas do povo, homens simples, vivendo em difíceis condições materiais, quase todos analfabetos, mas conhecidos como "Mestres". São artistas, homens que fazem a "brincadeira do mamulengo", criam e detêm o conhecimento sobre como se faz essa arte; são os portadores do patrimônio técnico, artístico e cultural do mamulengo.

O mamulengo consiste em um teatro do riso, como o são tantas outras formas dramáticas populares: “[...] no mamulengo todas as inverossimilhanças são permitidas porque nada é real e todo o prazer decorre das convenções, atingindo um realismo superior, mais verdadeiro que o verdadeiro, porque é poético" ${ }^{12}$.

A estruturação dramática obedece a um sistema de pequenas peças ou passagens não escritas, entremeadas por números de dança e por improvisações feitas pela personagem apresentadora, conhecida como Simão, Tiridá, João Redondo. Tratam-se de espetáculos de estruturação arbitrária, as passagens acontecendo de modo independente, sem muita preocupação de ligação lógica entre si. Embora se constituindo de peças ou passagens não escritas, o mamulengo pode ser considerado próximo ao "gênero revista", ou teatro de variedades, em que uma sucessão de pequenas passagens com assuntos cômicos, sociais, morais, religiosos se sucedem como esquetes, incorporando elementos que pertencem aos gêneros dos musicais e ao gênero do circo $^{13}$.

\footnotetext{
11 Em Pernambuco a manifestação é conhecida como Mamulengo, porém no Rio Grande do Norte é denominada João Redondo ou Calunga; na Paraíba, Babau; na Bahia, Mané Gostoso. BORBA FILHO, Hermilo. Fisionomia e espirito do mamulengo. Rio de Janeiro: Minc, Inacen, 1987. p. 55; PIMENTEL. Altimar de Alencar. O mundo mágico de João Redondo. Rio de Janeiro: Minc, Fundacen, 1988. p. 7.

12 BORBA FILHO, 1987, p. 227.

13 SANTOS, Fernando Augusto. Mamulengo: um povo em forma de bonecos. Rio de Janeiro: Mec: Funarte, 1987. p. 142.
} 
Por constituir uma tradição cuja prática vem desde a época do Brasil-Colônia, predominantemente agrário e escravocrata, o mamulengo representa simultaneamente uma dramaturgia e uma história de transmissão oral, em que foram sintetizadas personagens típicas, temas, fórmulas e estruturas, as quais têm inspirado desde então inúmeras adaptações, e formas de expressão artística. Os mestres das várias brincadeiras pernambucanas são também responsáveis pela criação de inúmeros versos e cantigas, expressões e ditos que freqüentemente se tornam populares e podem persistir, tornando-se típicos ${ }^{14}$.

A continuidade e preservação da arte do mamulengo estão intimamente ligadas à transmissão oral, na relação que se estabelece entre mestre e aprendiz, sobretudo a observação da prática, a forma de apresentar e "brincar" do mestre, pois estas são as características que preservam e sustentam a continuidade da brincadeira. $\mathrm{O}$ que é transmitido pelo mestre pode ser compreendido como "técnicas"15 ou "estruturas materiais ou imaginárias", ou ainda, "técnicas codificadas de longa duração". Para Eugenio Barba ${ }^{16}$, técnica é a "utilização extracotidiana do corpo", e para falar das técnicas codificadas refere-se a "princípios que retornam”. Os estudos de Barba concentram-se no treinamento corporal, na preparação psicofísica do ator, cuja história vai construindo um acervo composto de técnicas incorporadas por mestres do ofício, ao qual o aprendiz e seu seguidor recorrem e que as utilizam.

Os mamulengueiros vivem processos bastante semelhantes. Por isso, relacionar os estudos dessa arte com conceitos da antropologia teatral trabalhados por Barba ampliará a compreensão dessa manifestação. $O$ ensino do teatro de animação no Brasil deve estabelecer como prioridade o estudo dessa arte, apoiando-se em pesquisas, bem como na leitura e encenação de textos dramáticos do repertório do Mamulengo recolhido por pesquisadores ${ }^{17}$.

Nomenclaturas - É freqüente o uso de expressões como "teatro de marionetes", "teatro de bonecos", "teatro de formas animadas", "teatro de objetos", "teatro de animação" para designar essa linguagem. Muitas vezes essas nomenclaturas são usadas como sinônimos, mas existem diferenças entre elas. Atualmente a expressão mais aceita no Brasil é "teatro de animação", por se tratar de uma arte com a peculiaridade de animar a forma inanimada. É, de fato, a arte na qual a relação com a platéia é mediada pela presença do objeto animado.

14 DUTRA, Patrícia Angélica. Trajetórias de criação do mamulengo do professor Benedito em Chão de estrelas e mais além: ato, ritual arte e cultura popular. 1998. p. 180. (Dissertação) Programa de Pós-Graduação em Antropologia Social, Universidade Federal de Santa Catarina, Florianopólis, 1998. É possível registrar não só no Nordeste Brasileiro, mas em outras regiões do Brasil, a trajetória de grupos teatrais que têm sua base de inspiração no mamulengo. Observando sua estrutura e elementos presentes na brincadeira recriam o mamulengo, apresentando espetáculos originais, cujas referências são a arte dos mamulengueiros.

${ }^{15} \mathrm{Em} A$ arte secreta do ator, Barba e Savarese escrevem: "O modo como usamos nossos corpos na vida cotidiana é substancialmente diferente de quando usamos em situações de representação. $\mathrm{Na}$ vida cotidiana usamos uma técnica corporal que foi condicionada pela nossa cultura, nossa posição social e profissão. Mas, numa situação de representação, o uso do corpo é completamente diferente. Portanto, é possível diferenciar entre a técnica cotidiana e a técnica extracotidiana." BARBA, Eugenio; SAVARESE, Nicola. A arte secreta do ator. Dicionário de antropologia teatral. Campinas, SP: UNICAMP, 1995. p. 227.

${ }_{16}$ BARBA; SAVARESE, 1995 , p. 27-58.

17 Refiro-me a BORBA FILHO, 1987; CANELLA, Ricardo Elias Ieker. A construção da personagem no João Redondo de Chico Daniel. 2004. 178 p. (Dissertação) - Programa de Pós-Graduação em Ciências Sociais, Universidade Federal do Rio Grande do Norte, Natal, 2004; DUTRA, 1998; PIMENTEL, 1988; SANTOS, 1987. 
Também existem diferentes nomenclaturas para definir quem é o profissional que se expressa com a linguagem do teatro de animação. Historicamente, "titeriteiro" e "marionetista" foram as expressões mais utilizadas. No entanto, a partir de 1975 já se faziam rupturas estéticas visíveis em relação ao teatro de bonecos tradicional, e com o teatro geralmente produzido em escolas, bastante conhecido como "teatro de fantoches". E "bonequeiro" passou a ser a nomenclatura corrente. Mas logo apareceram outras designações, com a justificativa de que "bonequeiro" é a expressão mais adequada para quem trabalha com o boneco do tipo antropomorfo e, por isso, não aglutina tendências mais contemporâneas da linguagem.

A denominação mais aceita foi "manipulador", porque creditava a este artista a responsabilidade da encenação. No entanto, muitos profissionais da área passaram a considerá-la inadequada, porque pressupõe uma relação verticalizada do ator sobre o boneco ou objeto. Tal visão não contempla um aspecto fundamental no trabalho desse artista: o diálogo entre a matéria de que é feito o títere, os mecanismos de articulação e animação, assim como as intenções do ator-animador. Ou seja, a relação que se estabelece entre o artista que se expressa com bonecos e objetos ou formas animadas é mais complexa do que o sentido da palavra "manipulador" confere a este artista. Certamente por essa razão, mais recentemente é comum o uso de nomenclaturas como "ator-bonequeiro", "ator-animador". Isso evidencia a intenção de reafirmar a concepção de que o artista em questão é ator, é intérprete.

No entanto, ainda persistem as dúvidas que pairam sobre a denominação mais adequada ao trabalho desse profissional. Há o entendimento de que o ator-animador é um artista que encena espetáculos expressando-se com bonecos. E na realização desse trabalho, normalmente, concebe o texto: é dramaturgo; confecciona os bonecos, os objetos, o que lhe exige competências para esculpir, pintar, costurar: é escultor, pintor e figurinista; concebe e executa o cenário e materiais de cena: é cenógrafo e aderecista; seleciona a trilha sonora e, às vezes, compõe músicas para o espetáculo: é músico; interpreta utilizando bonecos e objetos para representar e, atualmente, é comum extrapolar os limites da "tenda" ou "palquinho" tradicional dos bonecos e atua numa relação direta com o público: é ator; dirige o próprio espetáculo: é diretor; concebe a iluminação para o espetáculo: é iluminador; levanta os recursos financeiros e as condições materiais para a realização do trabalho, além de divulgar e vender o espetáculo: é produtor; define o material gráfico, tais como programa e cartaz: assim, também é artista gráfico.

Como se vê, trabalhar com teatro de animação é atividade que envolve o conhecimento das práticas de outras profissões, exigindo a realização de tarefas que, mesmo não tendo formação na área, os atores-animadores precisam executar.

Os tipos mais comuns na confecção de bonecos são o boneco de fio, mais conhecido como marionete; boneco de luva, popularizado como fantoche; boneco de vara; marote; boneco à tringle, boneco de mesa ou balcão.

Boneco de fio, mais conhecido no Brasil como "marionete", é um boneco de confecção e manipulação complexa, porque, além de ter entre cinco e 30 fios, é um gênero que exige movimentos lentos e delicados, quase sempre próximos dos movimentos humanos ou animais. Boneco de luva, também chamado de fantoche, é sem dúvida o gênero mais popular do teatro de animação. A luva é a roupa do boneco, 
a mão e os dedos do marionetista constituem o corpo e fazem os movimentos do boneco. É conhecido como guignol (França), Don Cristóbal (Espanha), punch (Inglaterra), karspel (Alemanha), pulcinella (Itália), petrushka (Rússia) e mamulengo (Brasil), para citar apenas algumas das formas mais conhecidas. No Oriente também é uma arte muito praticada, sobretudo na China, local onde existem grandes virtuoses no gênero. Boneco de vara, derivado do Wayang, é o boneco tradicional da ilha de Java, na Indonésia, que é sustentado por uma vara principal que fixa sua cabeça e manipulado de baixo para cima. Normalmente, o boneco possui uma segunda vara em uma das mãos. Marote é uma variação simplificada do boneco de vara. Trata-se de um boneco montado em torno de uma única vara principal, presa na cabeça. Não possui varas que controlem as mãos, mas um bom marionetista sempre consegue tirar muitos efeitos, principalmente em cenas de dança e figurações. Boneco à tringle: originário do francês tringle, tem uma vara, haste de metal fixada na cabeça e também aparece com varas de manipulação fixas num pé ou mão. Geralmente apresenta movimentos bruscos e rápidos. Boneco de mesa ou balcão: manipulado por trás do corpo do boneco, o marionetista o apóia numa mesa ou balcão. Derivado do bunraku japonês, é um boneco que exige até três animadores para sua atuação. Difundiu-se amplamente no Ocidente a partir da segunda metade do século XX, originando diversas variantes. A mais conhecida é a forma de teatro em que os marionetistas se vestem de preto, atuam à vista do público e se tornam quase invisíveis devido ao jogo de luz.

A expressão do boneco - inerte, o boneco é um objeto, e o que o transforma em elemento teatral é a ação dramática, a interpretação diante do espectador. Ao animar o boneco, o ator-bonequeiro também atua. É equivocado pensar que quando o ator é deficiente em seu trabalho de intérprete, pode se realizar profissionalmente no campo do teatro de animação, porque ali se trabalha só com as mãos. "Dificilmente alguém pode ser um bom titeriteiro se não for bom ator"18.

Animar é transformar o objeto em personagem, e o que caracteriza o teatro de animação não é apenas o objeto em si, tampouco seu desenho, forma, peso, volume e material de que é construído, embora esses elementos sejam determinantes na sua animação e no processo de encenação do espetáculo. É a animação que faz com que ele exista, e só a ação justifica sua presença na cena. A vida presente nos bonecos cria uma outra realidade, e isso se deve ao trabalho do bonequeiro. Por isso, é possível afirmar que o boneco é a extensão do corpo do ator-animador.

A animação não pode ser confundida com a realização de qualquer movimento do objeto em cena e não tem obrigatoriamente relação com quantidade e intensidade de movimentos. O movimento sutil, mínimo, bem como o ampliado, brusco, ou seja, todo tipo de movimento pode fazer parte da animação, desde que tenha uma intenção. A ausência de movimento também pode ser uma ação da personagem. A animação dá a impressão de que o boneco tem autonomia, possui consciência, age por vontade própria. Como afirma Niculescu, "[...] é importante que as marionetes pensem. Uma marionete que não pensa é uma marionete manipulada"19.

\footnotetext{
${ }^{18}$ ERULI, Brunella. Le dernier pas dépend du premier. In: PUCK: la marionnette et les autres arts. Charleville-Mézières: Institut International de le Marionnette, 1994. n. 7, p. 85.

${ }_{19}$ Margareta Niculescu, então diretora da École Supérieure National des Arts de la Marionnette em Charleville-Mézières, França, em entrevista ao autor em 07 de dezembro de 1998.
} 
$\mathrm{O}$ ator-bonequeiro define e ordena a seqüência de gestos e ações que qualificam a presença do objeto/personagem. O desafio é produzir a impressão de vida num corpo que se encontra fora do seu próprio corpo. $\mathrm{O}$ que qualifica a animação é, portanto, a adequação dos movimentos, dos gestos, das ações selecionadas pelo ator-animador e pela direção do espetáculo com o conjunto da obra.

Atualmente, os espetáculos de teatro de animação têm utilizado com muita freqüência a presença visível do ator-animador no espaço de atuação, na cena. É comum ver espetáculos em que ele interpreta uma personagem e contracena com o boneco; às vezes é neutro em cena, atuando de modo a valorizar a performance do boneco. Registra-se ainda outra maneira, na qual, enquanto atua, estabelece uma relação de cumplicidade com o boneco.

Assim, quando se toma como referência o teatro de bonecos com a estética $\mathrm{da}$ manifestação popular, ou aquele pertencente às grandes tradições, como o Mamulengo, é possível constatar que o teatro feito atualmente usa variados meios de expressão, abandona o boneco do tipo antropomorfo, rompe com o palquinho do tradicional teatro de bonecos e se torna um teatro de animação bastante heterogêneo. Sua proximidade com outras linguagens artísticas, incluindo a dança, a mímica, o circo, o teatro de atores, as arte plásticas e o espetáculo multimídia torna esta arte reconhecidamente mais contemporânea, porém heterogênea, distanciada dos códigos e registros que historicamente a tornaram conhecida do grande público.

A heterogeneidade não elimina as especificidades próprias desse campo artístico, ao contrário, ela merece destaque no ensino dessa arte. Como afirma Jurkowski, “[...] o teatro de títeres é uma arte diferenciada do teatro de atores pela sua característica mais fundamental, ou seja, o sujeito que fala, que atua, [o boneco] faz uso temporal de fontes de poderes vocais e motoras que estão fora dele, não são seus atributos próprios”20. Essa diferença aparentemente simples se reveste de complexidade à medida que o desafio do ator-animador consiste em animar a forma inanimada, em transpor suas emoções ao títere.

Princípios da linguagem - outro aspecto a ser priorizado no ensino dessa arte é o conhecimento de princípios técnicos para a animação de bonecos e objetos. Existem "normas", que vistas em conjunto e de forma interligada, definem princípios da linguagem artística em estudo, como as listadas abaixo.

A “economia de meios” - princípio que se utiliza do mínimo de recursos para realizar determinada ação. Implica em selecionar os gestos mais expressivos, o movimento preciso, limpo, sem titubeios e claramente definido. É como compreender que "menos vale mais", ou seja, não é a quantidade de gestos que garante a qualidade da ação.

O "foco" é a definição do centro das atenções de cada ação. A noção de foco pode ser exemplificada em momentos em que o boneco projeta seu olhar para o objeto ou personagem com que contracena. Quando existem diversos bonecos em cena e apenas um está realizando alguma ação, todos dirigem seu olhar ao que age. Isso dá a noção de foco, define o lugar para onde o público deve concentrar seu olhar.

O "olhar como indicador da ação" - princípio que se realiza quando o boneco, antes do início de determinadas ações, olha para o ponto exato de deslocamento.

${ }^{20}$ JURKOWSKI, Henryk. Sobre el teatro de titeres. Bilbao: Concha de la Casa, 1990. p. 39. 
Este princípio também serve para destacar a presença de um objeto em cena. A precisão do seu olhar é determinante e indica ao espectador o que deve ser observado. Isso requer um movimento da cabeça amplo e definido, para dar a sensação de que o boneco olha. É comum ouvir de atores-bonequeiros experientes que "o boneco olha com a cabeça e não apenas com o olho".

A "triangulação" - recurso que se realiza com o olhar e colabora para "dialogar" com o espectador, fazendo-o "entrar" na cena. Trata-se de um "truque" efetuado com o olhar para mostrar ao espectador o que acontece na cena, evidenciar a reação de uma personagem, destacar a presença de um objeto. $O$ boneco interrompe a ação com o objeto (congela), dirige o seu olhar ao público, volta a olhar para o objeto e reinicia a ação ${ }^{21}$.

A "partitura de gestos e ações" - é a escrita cênica que detalha a seqüência de movimentos, ações e gestos de cada personagem no espaço, em cada uma das cenas do espetáculo. A construção da partitura é criação do ator-animador em parceria com o diretor, obedecendo a determinações das técnicas de animação, à matéria com a qual foram confeccionados os bonecos, às articulações da sua estrutura física e à conduta da personagem. Vale destacar ainda a vinculação existente entre os gestos e ações do boneco com os princípios estéticos do espetáculo. Portanto, a criação da partitura de gestos e ações não é criação aleatória do ator-bonequeiro: sua construção mantém estreitos vínculos com a concepção do espetáculo teatral.

O "subtexto" é uma criação interna do ator, pautada nas intenções de cada personagem, e que apóia a construção e apresentação da partitura de gestos e ações. Conforme Pavis, é "[...] aquilo que não é dito explicitamente no texto dramático, mas que se salienta na maneira pela qual o texto é interpretado pelo ator. O subtexto é uma espécie de comentário efetuado pela encenação e pelo jogo do ator, dando ao espetáculo a iluminação necessária à boa recepção do espetáculo"22. A construção do subtexto pode funcionar como guia ao ator-bonequeiro para sustentar a atuação da marionete.

"O eixo do boneco e sua manutenção" - consiste em respeitar a estrutura corporal e sua coerência com a coluna vertebral do ser humano, ou obedecer à postura animal quando a personagem é dessa origem. É importante aproximar o boneco da forma "natural" da personagem que representa. Exige observar a posição das pernas, coluna vertebral, verticalidade do corpo do boneco quando se trata de boneco do tipo antropomorfo. Quando o ator-bonequeiro não mantém o eixo corporal do boneco, colabora para a perda da credibilidade da personagem em cena, porque evidencia que ela está sendo manipulada.

"Relação frontal" - mantê-la é atuar de forma que o público não perca de vista a face (máscara) do boneco. Quando o boneco realiza ações que escondem totalmente seu rosto por tempo prolongado é difícil manter o foco e a atenção do espectador na cena. Assim, a personagem perde força e dá a impressão de que volta a ser o objeto ou a matéria da qual o boneco é confeccionado.

\footnotetext{
${ }^{21}$ Quando existem dois bonecos dialogando em cena, uma das maneiras mais comuns de realizar a triangulação é fazer com que o boneco que age e fala, olhe para o público enquanto é observado pelo outro boneco, que permanece imóvel. Ao terminar sua fala ou ação, devolve o olhar para o segundo e os papéis se invertem. Ou seja, o que age e fala, olha para o público enquanto é observado pelo outro boneco. Faz-se o triângulo: a personagem que atua, o público e a segunda personagem. Isso também define o foco da cena e capta a atenção do espectador.

${ }_{22}$ PAVIS, Patrice. Dicionário de teatro. São Paulo: Perspectiva, 1999. p. 368.
} 
"Movimento é frase" - trabalhar com essa noção supõe ultrapassar a idéia de movimentar aleatoriamente ou sacudir o boneco em cena. Implica em dissecar os movimentos, fazendo a "pontuação" adequada, incluindo "ponto" e "vírgulas”. Cada ação tem seus movimentos realizados numa seqüência que implica em finalizá-las para depois iniciar o movimento subseqüente. Remete à necessidade de cuidar da finalização de cada gesto ou ação. Ajuda a definir os diferentes ritmos presentes em cada ação. Binômios como ação-reação, imobilidade-movimento, silêncio-ruído, podem ser referências importantes para o ator-bonequeiro realizar esse trabalho.

A "respiração do boneco" - fazer com que o boneco "respire" complementa a noção de estar em movimento, de estar vivo. Encontrar o movimento justo para dar a idéia de que o boneco respira exige a ampliação desse movimento, uma vez que o boneco "respira" com o corpo inteiro Por isso, o ator-animador busca encontrar o movimento justo, para dar veracidade a essa respiração. Muitas vezes o boneco "respira" em sintonia com a respiração do seu animador. Muitos gestos são impulsionados pelo ato de inspirar. As emoções vividas pela personagem-boneco também estão relacionadas com a inspiração/expiração: reagir com raiva implica em respirar de forma distinta à que ocorre ao receber um afago. É necessário longo tempo de "convivência” com o boneco para encontrar o movimento justo. Trata-se de um movimento dilatado, diferente do ato de respirar humano, mas fundamental para dar qualidade à sua atuação. Quando a respiração é feita adequadamente, o boneco parece vivo e sua atuação torna-se convincente.

A “'neutralidade' do ator-bonequeiro em cena" - Este princípio tem gerado muitas controvérsias, porque é difícil conceber a idéia de presença neutra na cena, uma vez que tudo o que está no palco adquire significado. A "neutralidade” é aqui concebida como predisposição do ator-animador para estar a serviço da forma animada, tornar-se "invisível” em cena, atenuar sua presença para valorizar a do boneco. Supõe eliminar caretas, suspiros, olhares e economizar gestos do ator-animador para evidenciar as ações do boneco. Trata-se de trabalhar com a noção de consciência de estar em cena, o que exige movimentos comedidos, discretos, elegantes, suficientes para que se remeta o foco das atenções ao boneco presente na cena e não ao seu animador. Quando os gestos do ator-bonequeiro e sua presença são mais eloqüentes que a presença do boneco, cria-se um duplo foco que desvaloriza a cena ${ }^{23}$.

Quando o ator-animador conhece esses elementos, certamente realiza melhor o seu trabalho. Isso ocorre quando o ator-manipulador está imbuído do que diz Brecht: "[...] há muitos objetos num só objeto"24. Ou seja, ver além do aparente, olhar mais profundamente e ver a possibilidade do movimento, o "vir a ser" contido em cada objeto ou boneco. A técnica e a qualidade da animação nascem desse tipo de concepção, aliada, naturalmente, ao exercício diário, ao trabalho paciente e prolongado.

\footnotetext{
${ }_{23}$ Em $O$ ator e seus $d u p l o s$, Amaral discute esse tema e propõe uma série de exercícios para a compreensão e domínio desses princípios técnicos. AMARAL, Ana Maria. O ator e seus duplos. São Paulo: Senac: Edusp, 2001. 159 p.

${ }^{24}$ BRECHT apud KOUDELA, Ingrid. Brecht: um jogo de aprendizagem. São Paulo: Perspectiva, 1991. p. 80.
} 


\section{Considerações finais}

O ensino do teatro de animação deve privilegiar o aprendizado da mais peculiar característica dessa arte, ou seja, a interpretação, a representação mediada pelo objeto-boneco. Ainda que seja indispensável para sua atuação, o conhecimento necessário ao trabalho de ator não é suficiente. Ser ator não significa, necessariamente, ser ator-animador. A animação do objeto, incumbência principal desse artista, exige o domínio de técnicas e saberes que não são necessariamente do conhecimento do ator. Ao mesmo tempo, é preciso salientar que se o ator-bonequeiro se confinar nas especificidades dessa linguagem, dissociando-se do trabalho do ator, terá uma atuação incompleta e inadequada. Ou seja, o ator-animador não pode prescindir dos conhecimentos que envolvem a profissão de ator.

É possível considerar o teatro de animação como uma linguagem com regras próprias, que estão em permanente processo de transformação, podendo ser atualizadas, recriadas ou superadas. Os acontecimentos mais recentes nos distintos campos das artes revelam mudanças, evidenciando um movimento em direção à ampliação das formas de atuação que se mesclam com outras linguagens artísticas. O ensino do teatro de animação precisa, obviamente, considerar essa realidade.

Eis algumas das proposições a serem consideradas no ensino do teatro de animação. Mas é preciso repetir: essa atividade é relativamente nova nas universidades brasileiras e as diversas experiências que vêm sendo realizadas em distintas regiões do país certamente contribuem para o enriquecimento do ensino dessa arte. 


\section{REFERÊNCIAS}

ABIRACHED, Robert. La crisis del personage en el teatro moderno. Madrid: Asociación de Directores de Escena de España, 1997.

AMARAL, Ana Maria. O ator e seus duplos. São Paulo: Senac: Edusp, 2001.

AMARAL, Ana Maria. Teatro de formas animadas. São Paulo: Edusp, 1991.

BARBA, Eugenio; SAVARESE, Nicola. A arte secreta do ator. Dicionário de antropologia teatral. Campinas, SP: UNICAMP, 1995. p. 23-63, p. 227-243.

BELTRAME, Valmor. Animar o Inanimado: a formação profissional no teatro de bonecos. 2001. 303 p. Tese (Doutorado) - Escola de Comunicações e Artes, Universidade de São Paulo, São Paulo, 2001.

BORBA FILHO, Hermilo. Fisionomia e espírito do mamulengo. Rio de Janeiro: Minc, Inacen, 1987. p. 55-86.

CANELLA, Ricardo Elias Ieker. A construção da personagem no João Redondo de Chico Daniel. 2004. 178 p. (Dissertação) - Programa de Pós-Graduação em Ciências Sociais, Universidade Federal do Rio Grande do Norte, Natal, 2004.

CAVALIERE, Arlete. O inspetor geral de Gógol/Meyerhold. São Paulo: Perspectiva, 1996.

CRAIG, Edward Gordon. Da arte do teatro. Lisboa: Arcádia, 1973.

DUTRA, Patrícia Angélica. Trajetórias de criação do mamulengo do professor Benedito em Chão de estrelas e mais além: ato, ritual arte e cultura popular. 1998. 205 p. (Dissertação) - Programa de Pós-Graduação em Antropologia Social, Universidade Federal de Santa Catarina, Florianopólis, 1998.

ERULI, Brunella. Le dernier pas dépend du premier. In: PUCK: la marionnette et les autres arts. Charleville-Mézières: Institut International de le Marionnette, 1994. n. 7.

HORMIGÓN, Juan Antonio. Meyerhold: textos teóricos. Madrid: Asociación de Directores de Escena de España, 1992.

JARRY, Alfred. Todo ubú. Barcelona: Bruguera, 1980.

JURKOWSKI, Henryk. Sobre el teatro de titeres. Bilbao: Concha de la Casa, 1990.

KLEIST, Heinrich von. Sobre o teatro de marionetes. Rio de Janeiro: Sette Letras, 1997. 
KRISINSKI, Wladimir. Un desorden sofisticado. In: PUCK: el títere y las otras artes: cuerpos en el espacio. Bilbao: Institut International de la Marionnette: Centro de Documentación de Títeres de Bilbao, 1992. n. 4, p. 13-20.

KOUDELA, Ingrid. Brecht: um jogo de aprendizagem. São Paulo: Perspectiva, 1991.

MANGANI, Adelaida. Taller escuela de titiriteros del teatro general San Martin. Buenos Aires: Mimeografado, 1998.

MAETERLINCK. Maurice. Menus propus, le théâtre. In: PLASSARD, Didier. Les mains de lumière. Charleville-Mézières: Institut International de la Marionnette, 1996. p. 196-201. MEYERHOLD, Vsévolod. O teatro teatral. Lisboa: Arcádia, 1980.

MEYERHOLD, Vsévolod. Le théâtre de foire. In: PLASSARD, Didier. Les mains de lumière. Charleville-Mézières: Institut International de la Marionnette, 1996. p. 231-232.

NICULESCU, Margareta. L'Ecole Supérieure Nationale des Arts de la marionnette. Charleville-Mézières: Institut International de la Marionnette, 1998.

PIMENTEL. Altimar de Alencar. O mundo mágico de João Redondo. Rio de Janeiro: Minc, Fundacen, 1988.

PAVIS, Patrice. Dicionário de teatro. São Paulo: Perspectiva, 1999.

PLASSARD, Didier. L'acteur en Effigie. Paris: L’Age D`Homme, 1992.

SANTOS, Fernando Augusto. Mamulengo: um povo em forma de bonecos. Rio de Janeiro: Mec: Funarte, 1987. 